\title{
Analysis of the Wear on Machined Groove Profiles Using Reverse Engineering Technology
}

Josef Sedlak (0000-0002-9819-8259) ${ }^{1}$, Denisa Hrusecka (0000-0003-1459-0040) ${ }^{1}$, Felicita Chromjakova (00000002-5084-1153) ${ }^{1}$, Jozef Majerik (0000-0002-6577-1987)², Igor Barenyi (0000-0002-9296-600X)²

${ }^{1}$ Tomas Bata University in Zlín, Faculty of Management and Economics, Department of Industrial Engineering and Information Systems, Mostní 5139, Zlín 760 01, Czech Republic. E-mail: sedlak@utb.cz, hrusecka@utb.cz, chromjakova@utb.cz

${ }^{2}$ Department of Engineering, Faculty of Special Technology, Alexander Dubcek University of Trencin, Ku Kyselke 469, Trenčín 911 06, Slovak Republic. E-mail: jozef.majerik@tnuni.sk, igor.barenyi@tnuni.sk

One of the key components in making Industry 4.0 a reality includes machines that are able to produce re-quired products and components faster, more precisely and more flexibly than ever before based on so-called reverse engineering technology. Reverse engineering is a technology which enables rapid acquisition of data for CAD, CAM, CAE, thereby greatly shortening the development, design and fabrication of parts. In general, analog data is converted to digital data, which is further processed. The paper deals with the analysis of prototype models of disc milling cutters with different blade profiles. The inspection of the shape of the disc-type prototypes is based on the reading of the digitized reference CAD model (workpiece with machined grooves), the subsequent positioning of the digitized protrusions of the disc mill cutters (milling cutter with edge profile 1, milling cutter with edge profile 8) with respect to this reference CAD model, creating a colour map of the deviations at the selected points. The aim of the paper was to analyse the resulting wear (deviation of the dimensions at selected points) on the prototype of the disc milling cutters with the profiles of the blades 1 and 8 , which was simplified on the workpiece with the machined profiles of the grooves 1 to 4 .

Keywords: Disc Milling Cutter, Workpiece with Machined Grooves, Part Inspection, Wear, 3D Scanner

\section{Introduction}

Reverse engineering technology has been developing promisingly in recent years. It is typical for its reverse sequence of activities in comparison to the typical production process. Typical production process starts with a virtual CAD model created by a designer and after that, the real physical component is produced based on this model. In reverse engineering, a physical object is available at the beginning and it is converted into digital CAD model thereafter. A designer can further work with this model as needed using the available CAx data processing applications [1-4].

The technology of reverse engineering enables measuring data or controlling the component in relatively short time in comparison with classical measurement methods. Time needed for the measurement of the complicated component reduces from weeks to hours or days. Regarding the rising shape complexity of products, the significance of this technology is growing, especially in terms of profitability $[3,4]$.

\section{ATOS systems}

In case of highly demanding digitization applications, there are just ATOS systems that are widely used.
Because of their specific design including two CCD cameras and light projection, ATOS systems enable to calculate digitized data based on stereo method. The high quality of data created by the stereo methods is supported also by the combination of a reference point method with automatically linked individual views. ATOS is a leader in the field of high quality control applications and highly demanding industrial digitization. It is easily adaptable to different measurement sizes with and easy calibration based on supplied calibration elements [1-4].

The resulting set of measurement data is a high quality STL file, 3D point coordinates, cuts, contour lines, or quality output reports.

\subsection{Making test samples}

Digitalization is the process of acquiring a digital image in which the continuous image function $\mathrm{f}(\mathrm{x}, \mathrm{y})$ is substituted by the corresponding discrete function $\mathrm{I}(\mathrm{x}, \mathrm{y})$. Digitization includes the following two steps [1-5]:

- quantisation,

- sampling.

Converting a continuous function to its discrete 
equivalent is always associated with the occurrence of an error. The reason of it is the loss of a part of information from original continuous function. These errors can be minimized by a proper setting of digitization parameters, such as a quantization interval or sample rate. The way of digitization or used methods of reverse engineering are influenced by the following factors [1-5]:

- properties of a digitized object - $2 \mathrm{D} / 3 \mathrm{D}$, size, material, colour, outer surface or volume,

- quality requirements for digitized data - dimensional accuracy, amount of data, geometry outline (control points only or whole surface),

- use of digitization - for occasional control measurements, control in serial or automated production, etc.

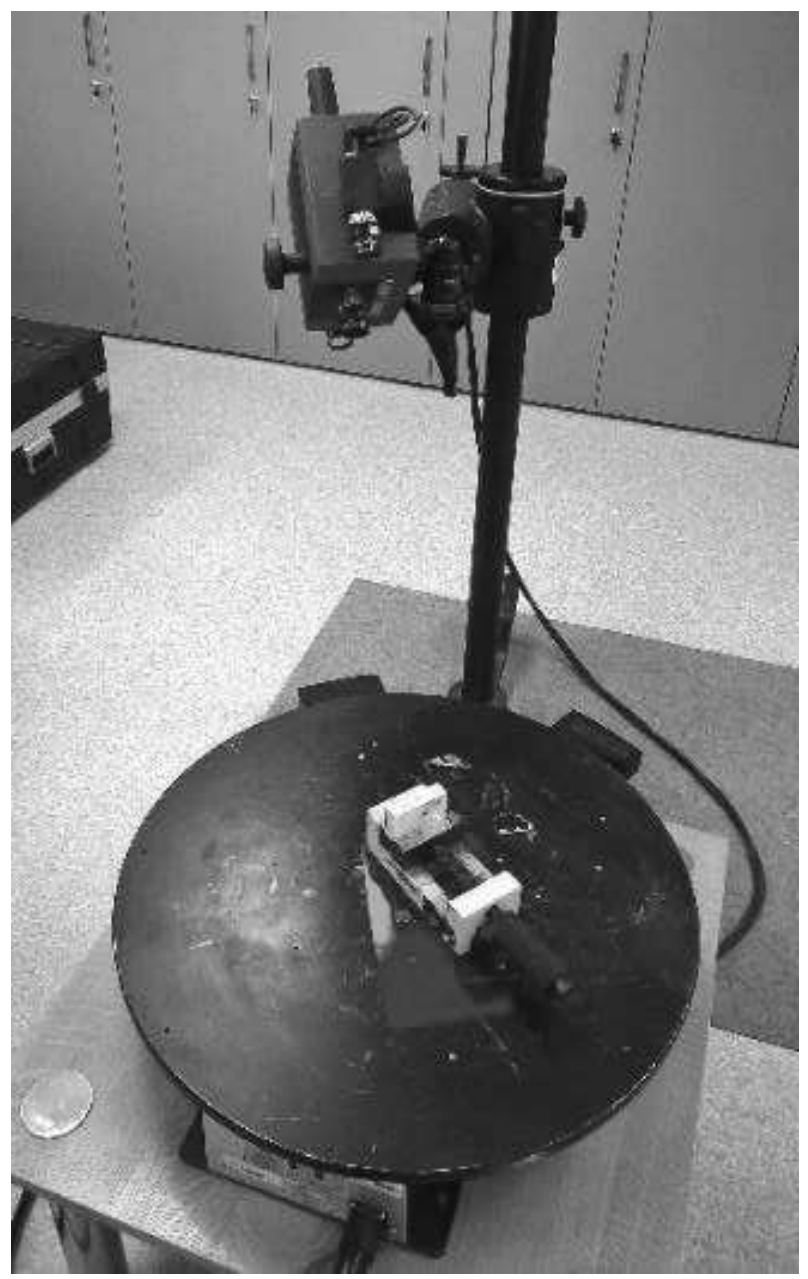

Fig. 1 Optical Scanner Atos Compact Scan 2M

ATOS Compact Scan 2M Optical Scanner (Fig. 1), which was used to digitize the cutter and workpiece with grooves, is based on ATOS blue-light projection technology. This technology includes two digital cameras of 2 million pixels resolution which capture light stripes projected by the scanner on the model surface. Advanced mathematical methods are used to automatically calculate the location of individual points in scanned space. The scanning process consists of the following main steps $[1,2,6,7]$ :

- preparation of disc cutter prototypes and workpiece machined grooves, see Fig. 2,

- the acquisition of individual scans, see Fig. 3,

- the joining and polygonization of individual scans, see Fig. 4,

- adjusting the polygonal mesh, see Fig. 5 .

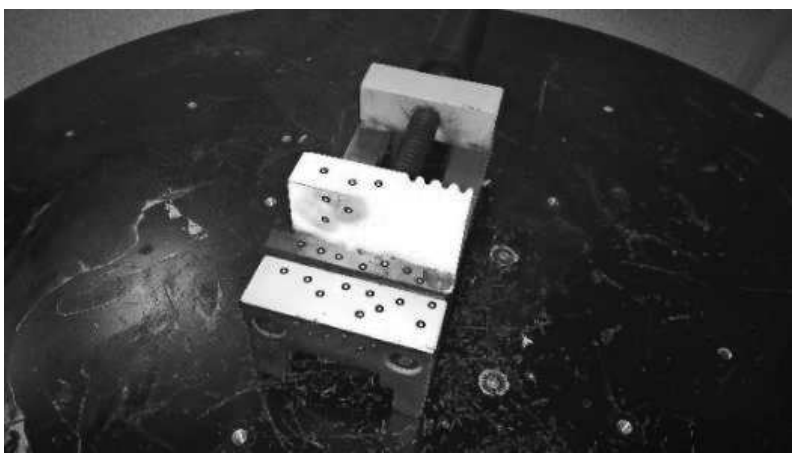

Fig. 2 Preparation of workpiece prototype with machined grooves

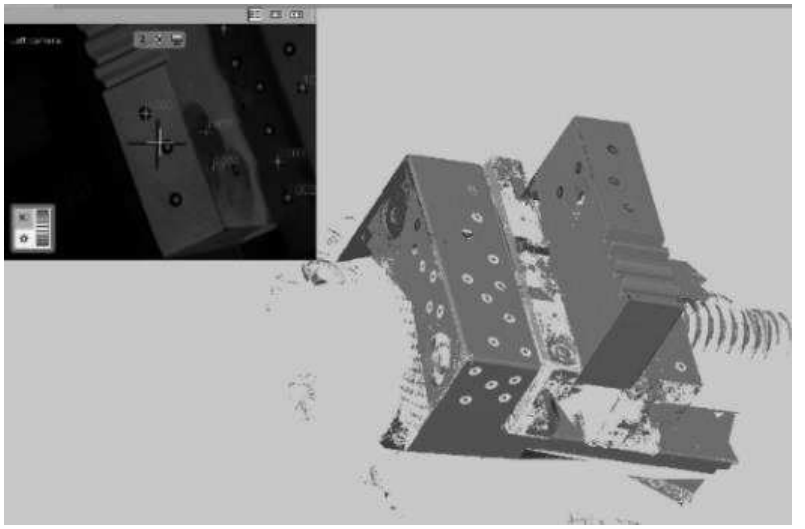

Fig. 3 Joining and polygonization of individual scans

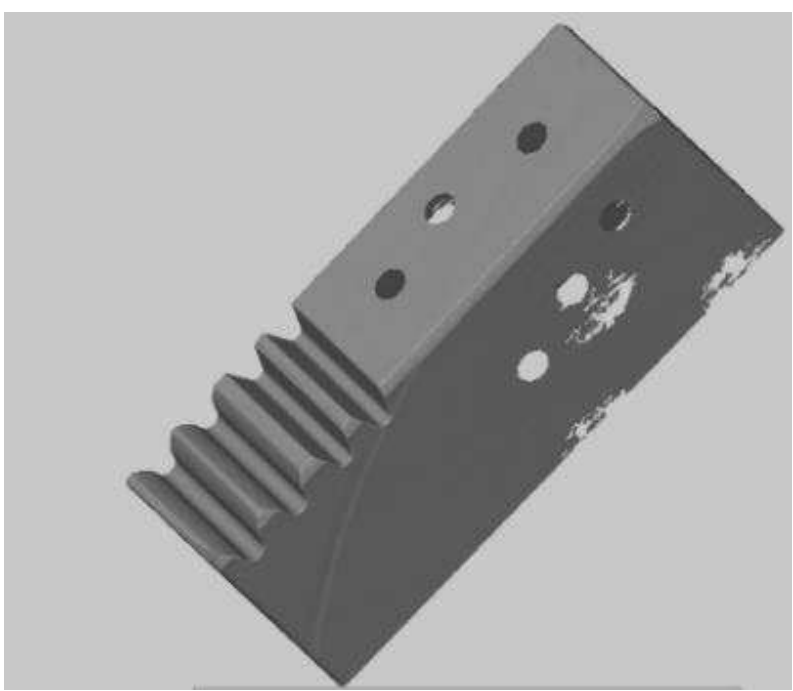

Fig. 4 The connection and polygonization of each scan 


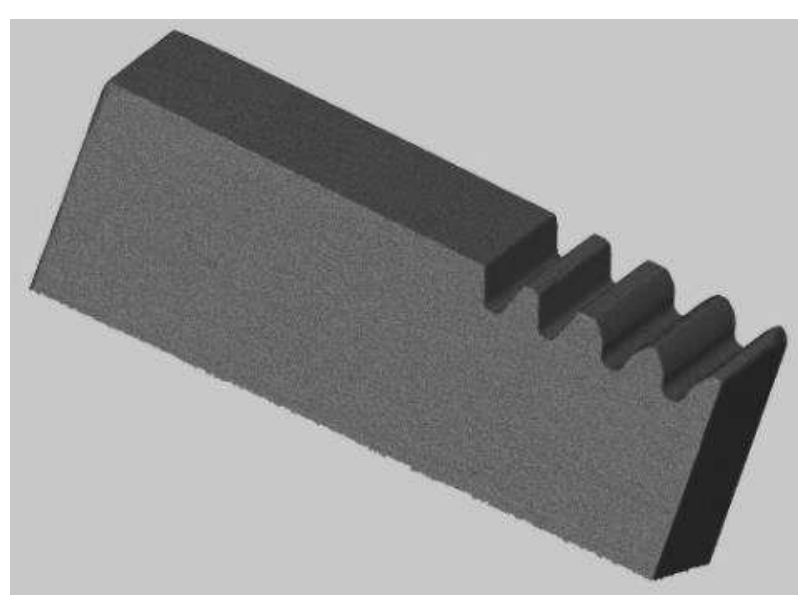

Fig. 5 Editing the polygon mesh of the workpiece prototype with machined grooves

\section{Triangulation}

One of the most widely used methods for objects digitization is triangulation. Fig. 6 shows its main principle. Firstly, a laser ray is sent to the measured object. After that the camera scan the ray reflection of the object surface. Value $b$ represents a distance between the source of ray and camera, and $\alpha$ is an angle between them. Camera, source of ray and the point of the ray incident create a triangle. The distance of the source from the object is calculated according to the following relationship (1) [1, 2, 8-12].

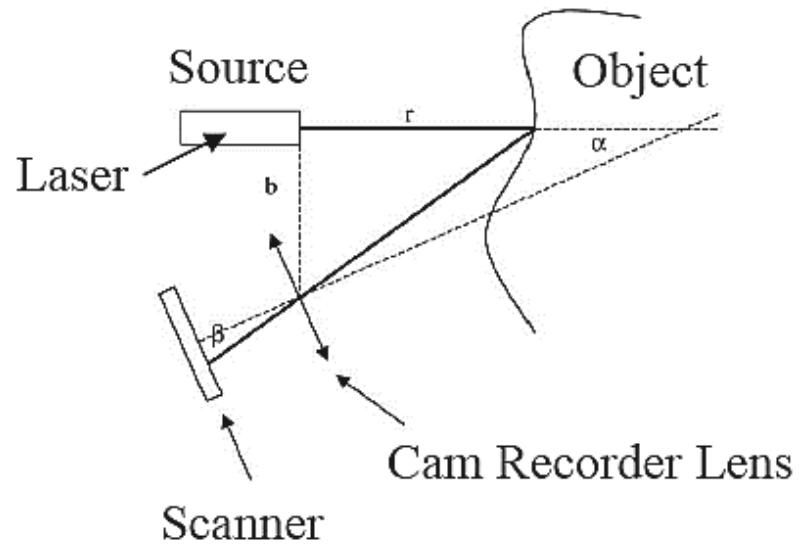

Fig. 6 Principle of triangulation [13]

Distance from object [11]:

$$
r=b \cdot \tan ^{-1} \cdot(\alpha+\beta)[\mathrm{mm}]
$$

Where:

$\alpha$ - the angle between the source and the camera $\left[^{\circ}\right]$, $\beta$ - the angle between the camera and the sensor $\left[{ }^{\circ}\right]$, $r$ - distance from the object [mm],

$b$ - source and camera distance [mm].

\section{Methods based on stereo vision}

As mentioned above, stereo vision based methods are very powerful in providing high quality data. The principle of stereoscopy enables to capture image using two cameras as described in Fig. 7. Each camera crate a $2 \mathrm{D}$ image of the scene from different angle. Based on these different positions of the points recorded by individual cameras (a disparity) and their mutual orientation, the resulting geometry is obtained. However, the stereo vision methods have also some weaknesses, such as the poor correspondence of the matching points in pictures containing a slight texture or edges. This weakness can cause consequent problems with inaccurate measurements and this is the reason why stereo vision method is often combined with certain active methods. Stereo vision based methods are very often applied in the area of advanced technology $[1,2,14]$.

\section{Left Cam Recorder Right Cam Recorder}

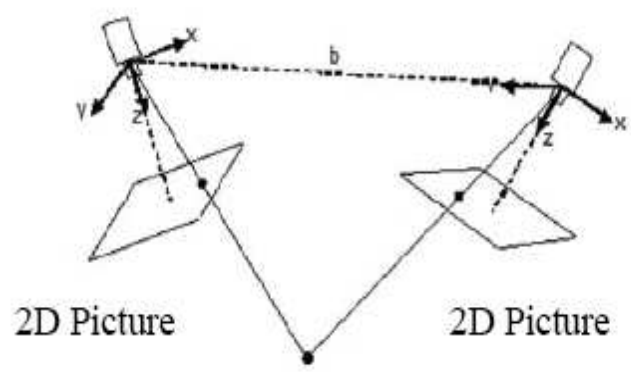

Point P

Fig. 7Typical Stereo Visual System [15]

\section{Fringe projection method}

The main principle of the fringe projection method is in projecting light stripes onto the scanned surface (Fig. 8). The light rays are deformed while they incidence an uneven surface. One or two cameras record the whole image and system calculates the coordinates of individual point is the space based on mathematical algorithm. The main advantage of this method is a large number of measured points from one image [1, $2,16,17]$.

\section{Projector Cam Recorder}

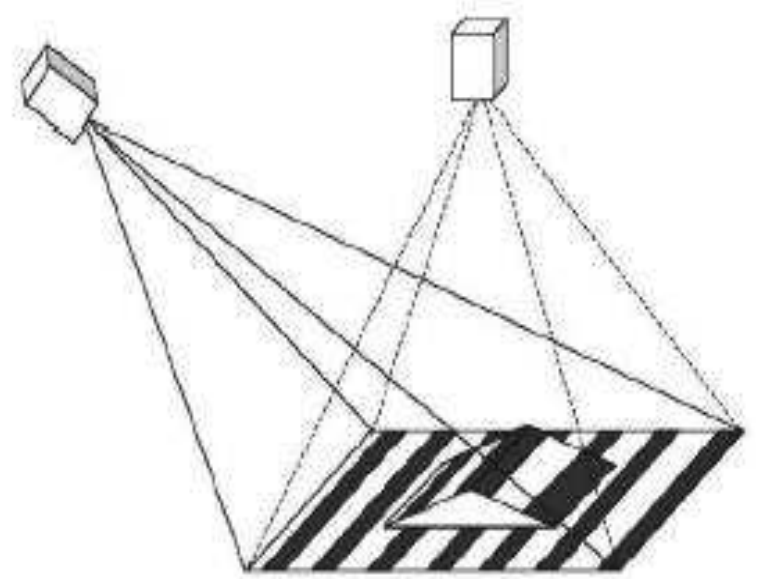

Fig. 8 Principle of Fringe Projection Method [13] 


\section{Digitisation of the shape of the disc mill cutter and workpiece prototype witch ma- chined grooves}

The digitization of the disc milling cutters and workpiece prototypes with machined grooves took place in several steps. The first step was the preparation of prototypes, which included the location of the reference points and the surface treatment, see Fig. 2. For the surface treatment $\mathrm{TiO} 2$ titanium powder was used, which serves to mitigate the surface of the scanned part since the device is not able to scan glossy surfaces on which the projected light reflected. The thickness of titanium powder deposition ranges from 0.003 to $0.004 \mathrm{~mm}$. Individual scans obtained from different angles were joined using appropriately positioned reference points which were automatically recognized. These points are necessary in order to evaluated the exact spatial position of all scans $[6,7,16,17]$.

When making individual scans, see Fig. 3 , it was possible to move both the workpiece prototype and the scanner. The scanned object is illuminated after focusing the scanner on target space and digitization process is initialized. It results in [1, 2, 6, 7, 16-24]:

- reference points capturing,

- light rays projection.

In the next step, the position of scanned points was calculated. As soon as all points and all scanned surfaces were displayed, it was necessary to align each single scan in order to smooth them. Scans with a large deviations were separated. After that, the polygonization was applied (Fig. 4) to approximate the triangular network based on scanned points. Fig. 5 shows the polygonal network which usually requires next adjustments, such as gluing of holes caused by reference points and another smooting and optimizing of final image (triangle reduction). Finished model was exported into STL format [1, 2, 6, 7, 16-24].

\section{Inspection on the shape of the disc mill cutters and workpiece prototypes with ma- chined grooves}

Inspection of the shape of the disc milling cutters and workpiece prototypes with machined grooves was performed using the ATOS Compact Scan 2M noncontact optical scanner. The analysed machine parts were the prototype of the disc mill cutters and the workpiece with machined grooves.

The inspection of the shape of the disc milling cutter and workpiece prototypes with machined grooves consisted in reading the digitized reference CAD model (workpiece with machined grooves), the subsequent setting of the digitized shape of the cutter prototypes (disc mill cutter 1, disc mill cutter 8 ) relative to this reference CAD model, dimension check and colour map deviation at selected points. The default data for the shape inspection was the polygonal network of the individual digitized protrusions of the disk mill cutters, shown in Fig. 9 [16, 17, 26, 27].

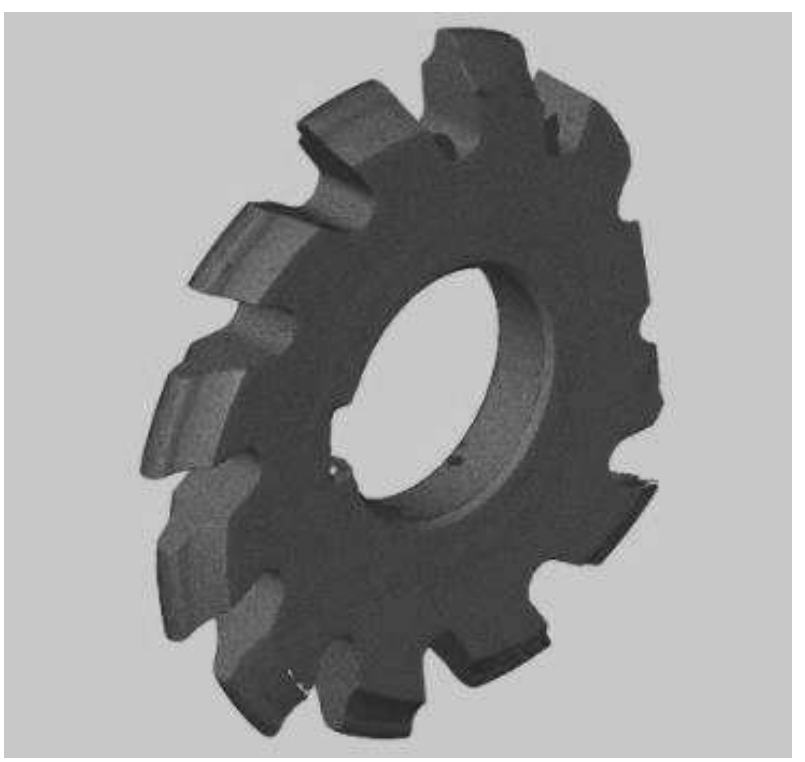

Fig. 9 Overall view of the formed polygon mesh of the milling cutter prototype with blade profiles 1

4.1 Component shape inspection - comparison of digitalized prototypes of disc mill cutters and reference $\mathrm{CAD}$ model

Instruments for measuring and comparing variations of the digitized shape of a disc milling cutter prototype and a reference CAD model (workpiece with machined grooves) were available in the GOM Inspect program. The context menu icon, as shown in Fig. 10, enables to align the scan and reference CAD model, compare the surface, do pointwise and other types of inspections or use I-inspect function for measuring distances, deviations, geometric tolerances and others. Before applying individual measurements, CAD data had to be imported and set on a polygon network [1, 2, 16, 17, 26, 27].

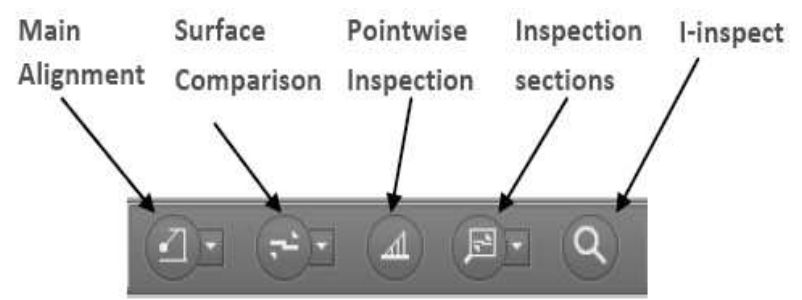

Fig. 10 Tools of Inspection icon menu [17]

\subsection{Import of a digitized reference $\mathrm{CAD}$ model}

After importing the digitized reference CAD model a new section called "Nominal elements" was added into element tree. The reference CAD model and the digitized model of the disc mill cutter prototype have so far used their coordinate systems and are not aligned with each other, see Fig. 11 [16, 17, 26, 27]. 


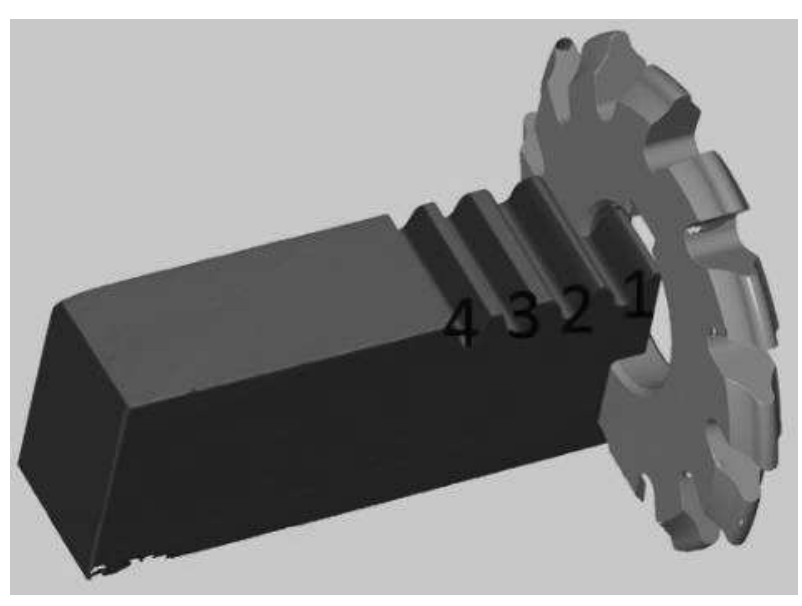

Fig. 11 Reference $C A D$ model and digitised prototype of disc milling cutter model with blade profiles 1 - not established

4.3 Establishing the reference CAD model and digitised model of the prototype disc milling cutter with blades 1 profiles

The principle of measurement was to determine whether the reference CAD model (workpiece with four machined grooves) corresponds to the prototype of the disc cutter mill with the profiles of the cutting edges 1 and 8 . For each prototype disk mill cutter with different cutting edges $(1,8)$ two grooves were formed in the workpiece the first groove created by the new tool should copy the profile of the cutter blades and the second groove created by the worn tool should reflect the differences (wear) [28, 29, 30].

The mutual alignment of both prototypes of the disc mill cutter with the blade profile 1 into the formed grooves in the workpiece was carried out by means of coordinate systems. Fig. 12 corresponds to the formed groove 1 (the reference groove produced by the first passage) by the newly used tool, and the groove 2 corresponds to the worn tool (the groove analysed after the last passage at the wear criterion $\mathrm{VB}=0.2 \mathrm{~mm}$ ) [28, 29, 30].

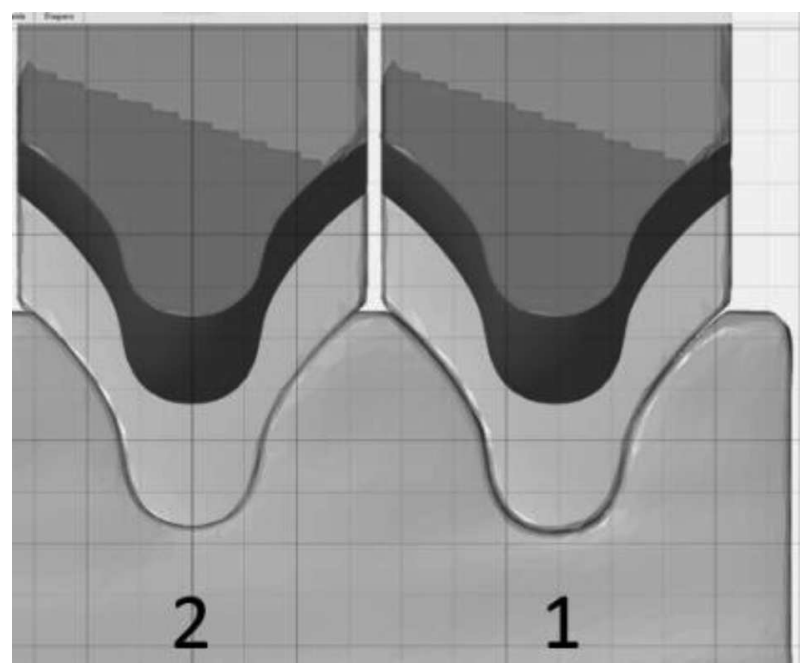

Fig. 12 Reference $C A D$ model and digitised prototype disc milling cutter prototype with blade profiles 1 - established
To simplify the whole matter, the resulting inspection was performed for the formed groove profiles 1 (reference) and 2 (analysed) using a disc mill cutter with blade profiles 1 . Since the titanium powder was applied to both grooves (or to the entire workpiece, respectively) it was not further considered in the final inspection [1, 2, 16-24].

\subsection{Displaying true shape deviations}

In one of the following step, deviations of the digitized shape were displayed through the main menu Inspection $\rightarrow$ CAD Comparison $\rightarrow$ Surface Comparison on $\mathrm{CAD}$. The range of the colourful legend can be modified according to user's requirements, but it must be always done with respect to desired part [1,2, $16,17,26,27]$.
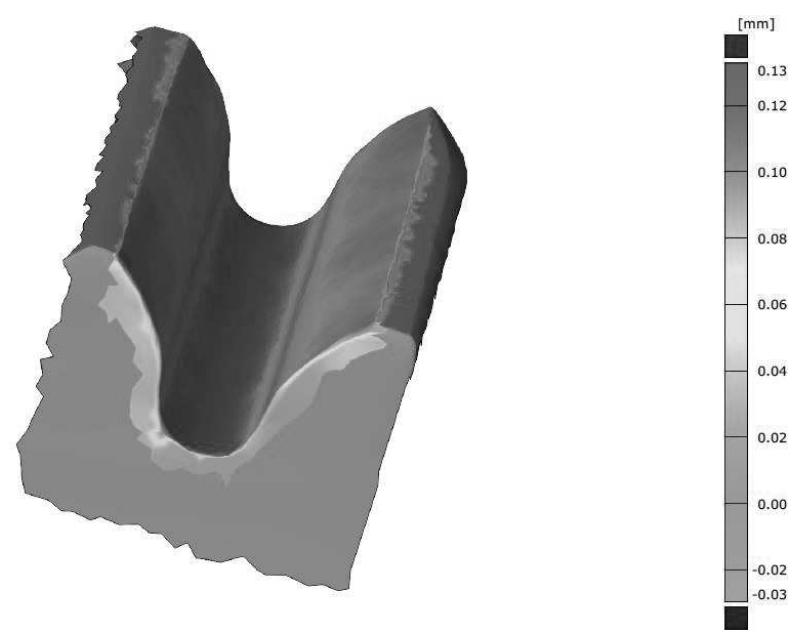

Fig. 13 Colour map of deviations

\section{Colour map of deviation}

Both created groove profile shapes were compared by using so-called colour maps (Fig. 13). This software comparison can be used also for comparing the element of the model with the ideal geometric element. This process starts with precise set of groove profiles in the same coordinate system and after that they are overlapped. In the next step, the surface of the overload patterns was covered by a texture that was generated according to the specific parameters. This texture was set to respect the rule that a certain colour or shade is assigned to a specific distance between measured points in several steps. For example, the red colour means that the maximum allowed distance between the surfaces was exceeded. In order to gain sufficient result, one of the measured groove patterns should be set as a reference one, it means that system consider it as an ideal and all distances are measured to it $[1,2,16,17,26,27]$.

\section{Discussion to reached results}

Inspection of prototype models: The formed profiles of grooves 1 (reference) and 2 (analysed) are 
shown in Fig. 11 and Fig. 12 when using a disc mill cutter with blade profiles 1 .

Displaying the resulting deviations at the selected points is shown in Fig. 14 and Fig. 15.

The reference CAD model was a digitized groove profile 1 (reference) and a model of the digitized groove profile 2 (analysed) was compared to this model, see Fig. 14 and Fig. 15 [31].

The results of the inspections of the prototype profiles of the grooves 1 and 2 using the disc mill cutter with the profiles of the blades 1 are as follows [31]:

- the ATOS Compact Scan 2M scanner has been digitized with the surface (external shape) of the individual prototype profiles of grooves 1 and 2, which were made by a disc mill cutter with blade profiles 1 ,

- the reference CAD model was the groove profile 1 against which the digitized groove profile 2 was compared,

- there was no asymmetry (imbalance) of the dimensions / deviations (scattering of values) during the inspection,

- the measured deviations of the dimensions at the selected points, see Fig. 16, correspond to the wear of the disc mill cutter with the profile of the blades 1 when the wear criterion $\mathrm{VB}=$ $0.2 \mathrm{~mm}$ is reached,

- for the purpose of digitizing the profiles of the grooves (or the entire workpiece), a titanium powder with a thickness of about 0.003 to $0.004 \mathrm{~mm}$ was applied on their surface, which eventually was not considered at the final inspection,

- all parts (workpiece and both disc mill cutters) were digitized with an accuracy of approx. 0.02 to $0.04 \mathrm{~mm}$, which corresponds to the colour map display of the deviation map (zero value corresponds to the green colour),

- for the digitization of all parts (workpiece and two disc mill cutters), the measuring range of $125 \times 90 \times 90 \mathrm{~mm} 3$ was absorbed by the ATOS Compact Scan 2M optical scanner, which is a boundary (usable) measuring device with respect to the dimensions of the workpiece and both disc milling cutters range,

- figs. 14 and 15 are confirmed by two different ways of achieving the same deviation of approximately $0.12 \mathrm{~mm}$ on the groove bottom, which reflects the wear of the tool used (disc mill cutter with blade profiles 1).
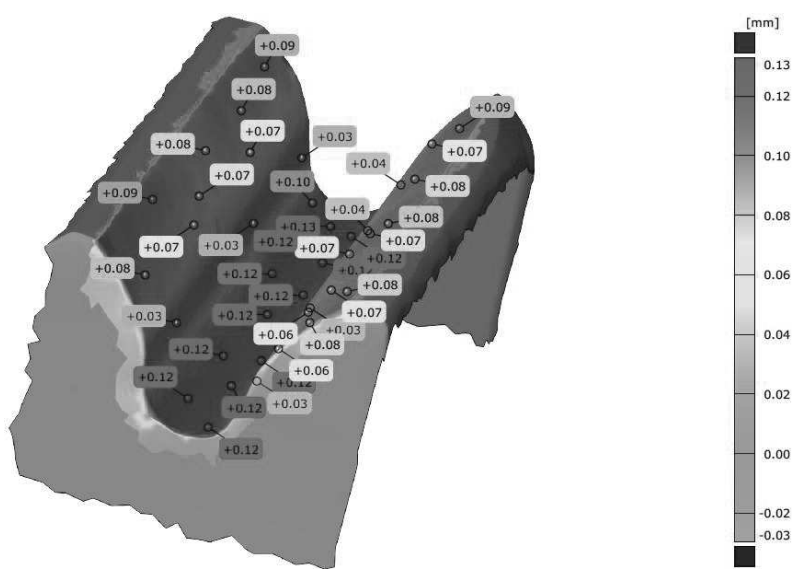

Fig. 14 Inspection of the prototype profiles of the grooves 1 and 2 with the use of a disc milling cutter with blade profiles 1
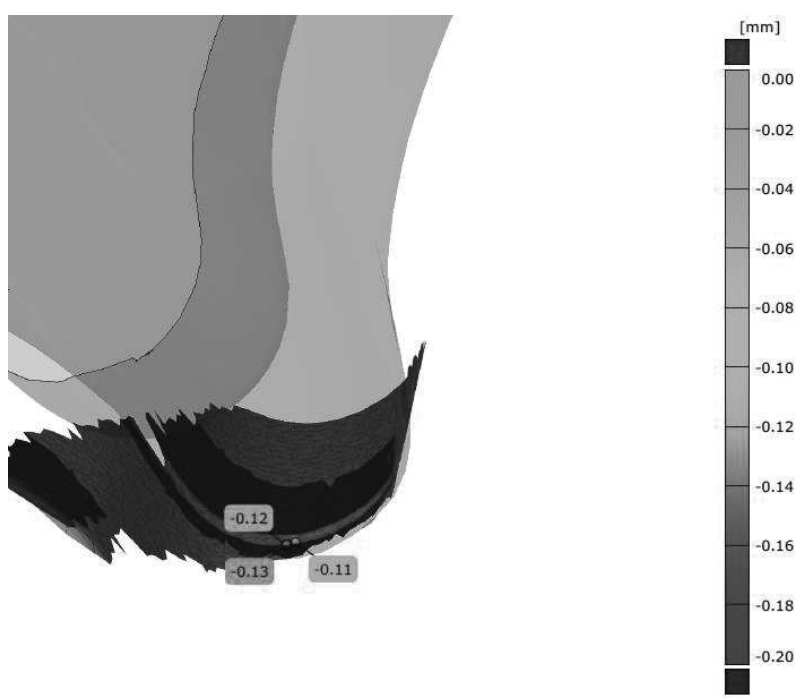

Fig. 15 Inspection of the prototype profile of the groove 2 using a disc milling cutter with blade profiles 1
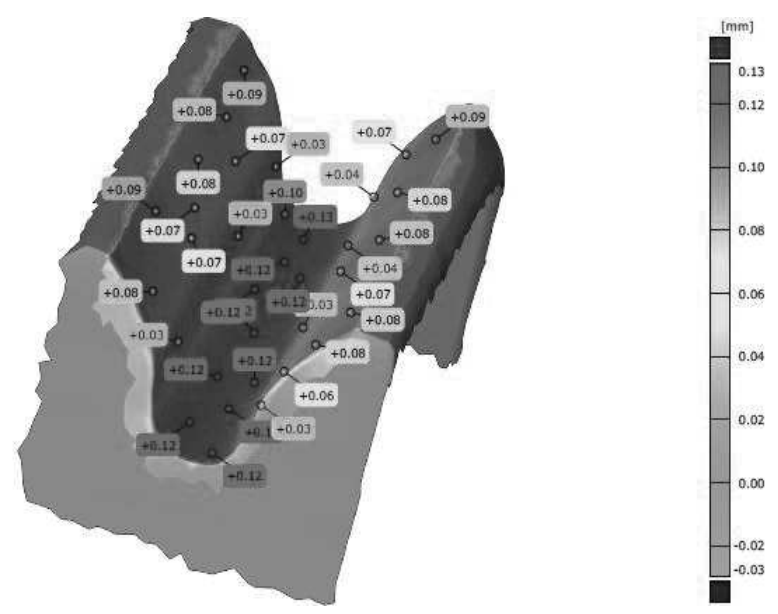

Fig. 16 Inspection of the prototype profiles of the grooves 1 and 2 with the use of a disc milling cutter with blade profiles 1

Remark:

Analogous inspection of the shape of the reference CAD model and the digitized model of the disc mill 
cutter prototype with the blade profiles 8 was also performed.

To simplify the whole matter, the resulting inspection was performed for the formed groove profiles 3 (reference) and 4 (analysed) using a disc mill cutter 8 with blade profiles 8 .

Due to the fact that the titanium powder was applied to both grooves (or to the entire workpiece), it was not considered further in the final inspection.

The results of the inspections of the prototype profiles of the grooves 3 and 4 using a disc mill cutter with the profile of the cutting edges 8:

- the measured (measured) deviations of the dimensions at the selected points, see Fig. 17, corresponds to the wear of the disc mill cutter with the profile of the blades 8 when the wear criterion $\mathrm{VB}=0.2 \mathrm{~mm}$ is reached.
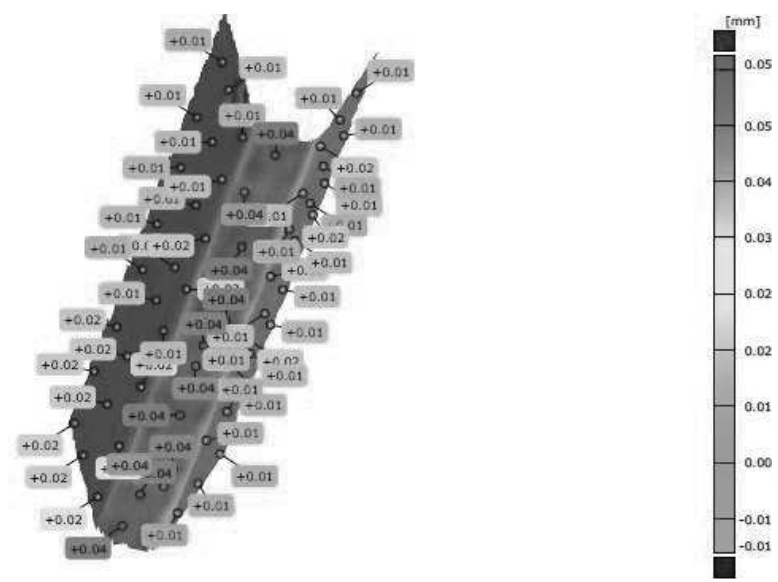

Fig. 17 Inspection of the prototype profiles of the grooves 3 and 4 with the use of a disc milling cutter with blade profiles 8

\section{Conclusion}

Reverse engineering methods could be a very useful tool in situations when 3D documentation is missing and target object should be reconstructed. With enough sufficient information available, the data obtained by digitization could be combined with an ideal $3 \mathrm{D}$ model created according to $2 \mathrm{D}$ documentation. This approach supports currently highly discussed digital transformation of industrial companies in a spirit of Industry 4.0.

When scanning of a real object, a number of various measurements can also be performed by using appropriate software tools. This is an advantage of reverse engineering, because these measurements would not be so easily practicable using another ways $[1,2]$.

The aim of the paper was to perform the inspection / analysis of prototype profiles of four grooves (grooves 1, 2 and grooves 3,4) made using two prototype disc milling cutters (milling cutter with blade profile 1 , mill cutter with blade profile 8 ). The results show that deviations of measured dimensions at the selected points, see Figs. 16 and 17, correspond to the wear of the disc milling cutters (with the profiles 1 and 8 ) at the wear criterion $V B=0.2 \mathrm{~mm}$.

Using a disc milling cutter with blade profiles 8 , the deviations found were significantly lower (approx. $+0.04 \mathrm{~mm}$ ) compared to the use of a disc mill cutter with blade profiles 1 , where the deviations found at the bottom of the slot were $+0.12 \mathrm{~mm}$.

The optical scanner performed non-contact, fast and accurate measurements with subsequent processing and evaluation of the achieved results (dimensional deviations at selected points). The measuring equipment used is one of the most reliable tools, especially for application in the field of engineering technology not only in the actual digitization of objects, but also in their subsequent inspection.

ATOS scanners, that were used in our study, are highly accurate and reliable devices. One of the benefits of this scanner is the continuous monitoring of the situation before, during and after measurement. The relative movement of the scanner and measured object is monitored while scanning as well as the change of ambient light. The scanner calibration is checked during every single measurement. Moreover, the new Blue Light projection technology of ATOS scanners is resistant to changing ambient lighting. Their accuracy is determined by VDI standards for optical systems (VDI 2634). The usage of 3D scanners is suitable for complex components with general surfaces. Digitized data provides information about the component dimensions, their geometric deviations or deviations of individual points $[1,2]$.

\section{Acknowledgement}

This publication was also created in the frame of the project: Advancement and support of R\&D for "Centre for diagnostics and quality testing of materials" in the domains of the RIS3 SK specialization, ITMS2014+:313011W442, based on the Operational Programme Integrated Infrastructure and funded from the European Regional Development Fund.

\section{References}

[1] SEDLÁK, J., POLZER, A., CHLADIL, J., SLANÝ, M., JAROŠ, A. (2017). Reverse Engineering Method Used for Inspection of Stirrer' s Gearbox Cabinet Prototype. In: MM Science Journal, Vol. 17, No. 4, pp. 1877-1882. ISSN 1803-1269.

[2] SEDLÁK, J., POLZER, A., CHLADIL, J., SLANÝ, M., JAROŠ, A. (2017). Shape Inspection of Gear Prototypes Using Reverse Engineering Method. In: Manufacturing Technology, Vol. 17, No. 6, pp. 945-952. ISSN 1213-2489. 
[3] PÍŠKA, M. et al. (2009). Speciální technologie obrábèní. CERM, Brno. 1st ed. ISBN 978-80-2144025-8.

[4] NAVRÁTIL, R. (2000). Reverse Engineering v praxi. [online]. Červen 2000 [cit. 2017-02-20]. Dostupné z: http://robo.hyperlink.cz

[5] SEDLÁK, J. (2008). Moderní technologie reverzního inženýrství - využití 3D skenerů. In: Technik, Vol. 16, No. 3, pp. 38-39. ISSN 1210616X.

[6] SEDLÁK, J. (2008). Technologie výroby prototypů spodporou reverz̨ního inženýrství a $C A D / C A M$ : Disertační práce. Brno: Vysoké učení technické v Brně, Fakulta strojního inženýrství, Ústav strojírenské technologie, 104 s., 11 př́loh. Vedoucí disertační práce doc. Ing. Miroslav PÍŠKKA, CSc.

[7] ZOUHAR, J., PÍŠA, Z., SEDLÁK, J., SEDLÁČEK, J. (2007). Produktivní obrábění s využitím metod reverzního inženýrství. In: Sbornik odborné konference „Frézováni IV“. Brno: VUT-FSI, Ústav strojírenské technologie ve spolupráci s PRAMET TOOLS, s.r.o. Šumperk a ZPS Frézovací nástroje, a.s., Zlín, 31.1.2007, s. 189-196. ISBN 80-214-3239-X.

[8] RAJA, V., FERNANDES, K. J. (2008). Reverse engineering: an industrial perspective. Springer, London. ISBN 978-1-84628-855-5.

[9] SEDLAK, J., PROCHAZKOVA, J. (2007). Direct B- Spline Interpolation of CNC Tool Trace From Cloadpoints. In: Manufacturing Technology, Vol. 7, No. 1, pp. 66-71. ISSN 1213-2489.

[10] SEDLÁK, J., PROCHÁZKOVA, J. (2007). Direct B-Spline Interpolation of CNC Tool Trace From Cloadpoints. In: Strojirenská technologie, Vol. 12, No. 2, pp. 24-28. ISSN 1211-4162.

[11] STYLIANOU, G., FARIN, G. (2003). Crest lines extraction from 3D triangulated meshes. In: Hierarchical and geometrical methods in scientific visualization, pp. 69-81. ISBN 978-3-642-55787-3.

[12] WEBER, CH., HAHMANN, S., HAGEN, H. (2010). Methods for feature detection in point cloud. In: Visualization of Large and Unstructured Data Sets-IRTG Workshop, pp. 90-99.

[13] PIERACCINI, M., GUIDI, G., ATZENI, C. (2001). 3D digitizing of cultural heritage. In: Journal of Cultural Heritage 2, Vol. 1, pp. 63-70. [online]. [seen 2017-03-12]. Available at: http://www.sciencedirect.com/science/article/pii/S1296207401011086
[14] 3D mërení. (2009). MAPV 2009. [online]. [cit. 2017-02-20]. Dostupné http://www.uamt.feec.vutbr.cz/vision/TEACHING/MAPV/08\%20$\% 203 \mathrm{D} \% 20$ mereni.pdf

[15] 3D Imaging with NI LabVIEW. (2012). National Instruments. [online]. [seen 2017-03-15]. Available at: http://www.ni.com/white-paper/14103/en

[16] MCAE SYSTEMS, s.r.o., Kuřim, ČR. 3D mérení, inspekce a skenování. [online]. [cit. 2017-0405]. Dostupné z: http://www.mcae.cz/cs/sluzby/3d-mereni-inspekce-a-skenovani/

[17] GOM GmbH, Schmitzstraße, Germany. Precise Industrial 3D Metrology. [online]. [seen 2017-0307]. Available at: http://www.gom.com/3dsoftware/gom-inspect.html

[18] SADÍLEK, M., ČEP, R., SADÍLKOVÁ, Z., VALÍČEK, J., PETŘKOVSKÁ, L. (2013). Increasing Tool Life During Turning with a Variable Depth of Cut. In: Materiali in Technologije, Vol. 47, No. 2, pp. 199-203. ISSN 1580-2949. UDK 621.941:004.896.

[19] ČEP, R., JANÁSEK, A., MARTINICKÝ, B., SADÍLEK, M. (2011). Cutting Tool Life Tests of Ceramic Inserts for Car Engine Sleeves. In: Tehnickei Vjestnik, Vol. 18, No. 2, pp. 203-209. ISSN 1330-3651. UDC/UDK 621.9.025:620.169.1.

[20] DUbOVSKÁ, R., MAJERÍK, J., ČEP, R., KOUŘIL, K. (2016). Investigating the influence of cutting speed on the tool life of a cutting insert while cutting DIN 1.4301 steel. In: Materiali in Tehnologije, Vol. 50, No. 3, pp. 439-445. ISSN 1580-2949.

[21] MAJERÍK, J., DUBOVSKÁ, R., JAMBOR, J., ČEP, R., KRATOCHVÍL, J., KOUŘIL, K. (2018). Experimental Investigation into Wear and Tool Life of Milling Cutter PVD Coated Carbide Inserts While Armox 500 Steel Hard Milling. In: Tehnički Vjestnik, Vol. 18, No. 6, pp. 1603-1610. ISSN 1330-3651.

[22] POKORNÝ, Z., BARBORÁK, O., HRUBÝ, V. (2012). Characteristics of Plasma nitride layers in deep Holes. In: Kovové Materiály, Vol. 50, No. 3, pp. 209-212. ISSN 0023-432X.

[23] POKORNÝ, Z., DOBROCKÝ, D., KADLEC, J., STUDENÝ, Z. (2018). Influence of alloying elements on gas nitriding process of 
high-stressed machine parts of weapons. In: Kovové Materiály, Vol. 56, No. 2, pp. 97-103. ISSN 0023-432X.

[24] SEDLÁK, J., VANĚK, R., CHLADIL, J. (2018). Production of Assistance Brake for Mechanical Wheelchair. In: Manufacturing Technology, Vol. 18, No. 3, pp. 487-492. ISSN 1213-2489.

[25] SEDLÁK, J., KUDLÁČOVÁ, B., ZEMČÍK, O., JAROS, A., SLANÝ, M. (2017). Production of Planetary Mechanism Model Prototype using Additive Method of Rapid Prototyping. In: Manufacturing Technology, Vol. 2017, No. 3, pp. 374-381. ISSN 1213-2489.

[26] FRVŠ. (2013). Financovaný projekt 1393/2013 - A/a, Prostorový skener pro výnku reverzníbo inženýrství. Hlavní řešitel: prof. Ing. Václav Pištěk, DrSc.

[27] Inspekece tvaru soućásti. [online]. [cit. 2017-02-15]. Dostupné http://www.iae.fme.vutbr.cz/userfiles/ra-
mik/files/Studium/Podklady $\% 20 \mathrm{ke} \% 20$ studiu $/ 3 \mathrm{D} \% 20$ skenov $\% \mathrm{C} 3 \% \mathrm{~A} 1 \mathrm{n} \% \mathrm{C} 3 \% \mathrm{AD} / \mathrm{E}-$ learning-Inspekce $\% 20$ tvaru $\% 20$ soucasti.pdf

[28] PAPROCKI, M., WYGODA, M., WYCZESANY, P., BAZAN, P. (2021). Symptoms of Wear HSS Cutting Tools in Different Wear Stages. In: Manufacturing Technology, Vol. 21, No. 3, pp. 387-397. ISSN 1213 2489.

[29] MAJERIK, J., BARENYI, I. (2018). Wear and Tool Life Investigation of Carbide Inserts while Hard Machining of Armox 500 Steel. In: Manufacturing Technology, Vol. 18, No. 2, pp. 273278. ISSN 1213-2489.

[30] POPOV, A., BABAK, S. (2018) Effect of Cutting Modes and Tool Wear on the Microhardness of the Surface Layer after Face Milling of Structural and Stainless Steels. In: Manufacturing Technology, Vol. 18, No. 6, pp. 10111014. ISSN 1213-2489.

[31] SEDLÁK, J., POLZER, A., SLIWKOVÁ, P. (2016). Digitalizace prototypu ozubených kol pomocí optickébo skeneru ATOS Compact Scan 2M, pp. 1-24. VUT, Brno. 